Jurnal Kebijakan Pembangunan Daerah, Vol.5, No.1, Juni 2021, Hal. 9 - 23

p-ISSN: 2597-4971, e-ISSN: 2685-0079

\title{
PENGARUH AKSES TEKNOLOGI INFORMASI DAN KOMUNIKASI \\ TERHADAP PERTUMBUHAN EKONOMI PROVINSI BANTEN \\ TAHUN 2015-2019
}

\section{THE EFFECT OF ACCESS TO INFORMATION AND COMMUNICATION \\ TECHNOLOGY ON ECONOMIC GROWTH OF BANTEN PROVINCE}

\author{
IN 2015-2019
}

\author{
(disubmit 21 Februari 2021, direvisi 26 April 2021, diterima 01 Juni 2021) \\ Reza Septian Pradana ${ }^{1}$ \\ ${ }^{1}$ Fungsional Statistisi Ahli BPS Kabupaten Aceh Jaya \\ Jalan Banda Aceh-Meulaboh Km 152, Keutapang, Calang, Aceh Jaya \\ E-mail: reza.sp@bps.go.id
}

\begin{abstract}
Teknologi Informasi dan Komunikasi (TIK) telah menjadi sumber daya baru bagi pertumbuhan ekonomi. Penelitian ini bertujuan untuk menganalisis pengaruh akses teknologi informasi dan komunikasi (TIK) terhadap pertumbuhan ekonomi di Provinsi Banten. Penelitian ini menggunakan analisis data panel delapan kabupaten/ kota di Provinsi Banten tahun 2015-2019. Hasil estimasi dengan random effect model menunjukkan bahwa akses teknologi informasi dan komunikasi yang diukur dengan variabel persentase pengguna komputer, internet, dan telepon seluler secara signifikan berpengaruh positif terhadap pertumbuhan ekonomi kabupaten/kota di Provinsi Banten. Dengan demikian, pemerintah perlu meningkatkan infrastruktur teknologi informasi dan komunikasi pada seluruh kanupaten/ kota di Provinsi Banten disertai upaya peningkatan kualitas penduduk dan tenaga kerja dalam pemanfaatan teknologi informasi dan komunikasi.
\end{abstract}

Kata kunci: informasi, komunikasi, pertumbuhan ekonomi, teknologi

\begin{abstract}
Information and Communication Technology (ICT) has become a new resource for economic growth. This study aims to analyze the effect of access to information and communication technology (ICT) on economic growth in Banten Province. This study used panel data analysis of eight regencies/ cities in Banten Province period 20152019. The estimation results using the random effect model show that access to information and communication technology measured by the variable percentage of computer, internet and cellular phone users has a significant positive effect on economic growth of regencies/ cities in Banten Province. Thus, the government needs to improve information and communication technology infrastructure in all regencies/ cities in Banten Province along with efforts to improve the quality of the population and labours in the use of information and communication technology.
\end{abstract}




\section{Keywords: information, communication, economic growth, technology}

\section{PENDAHULUAN}

Teknologi Informasi dan Komunikasi (TIK) telah menjadi sumber daya baru bagi pertumbuhan ekonomi. Menurut Kagermann dkk, (2013), TIK mencukupi kebutuhan apa saja yang diinginkan pelanggan secara individu, adanya proses rekayasa bisnis yang dinamis, opptimalisasi dalam pengambilan keputusan, serta munculnya model bisnis baru dan lahirnya inovasi dalam mencapai nilai tambah. Pemberdayaan TIK akan memacu inovasi dan kewirausahaan, meningkatkan produktivitas dan efisiensi operasi bisnis, menyediakan layanan pengembangan bisnis yang relevan, memfasilitasi hubungan ke pasar lokal, regional, dan internasional, memungkinkan akses ke teknologi baru dan sumber keuangan (UNIDO, 2018).

Pemerintah Indonesia juga menaruh perhatian penuh terhadap perkembangan TIK dengan mengeluarkan Undang-undang No 19 tahun 2016 mengenai perubahan atas Undang-undang Nomor 11 tahun 2008 tentang Teknologi Informasi dan Transaksi Elektronik (ITE). Undangundang ini telah menjadi payung hukum pemanfaatan TIK, khususnya teknologi informasi dan transaksi elektronik. Selain itu, pemerintah Indonesia melalui Kementerian Komunikasi dan Informatika selama periode 2010-2015 juga telah mencapai target pembangunan di bidang komunikasi dan informatika antara lain dengan menetapkan kebijakan dan regulasi yang progresif seperti kebijakan Tata Kelola E-commerce, Nusantara Internet Exchange (NIX) yang berada di 19 provinsi dan International Internet Exchange (IIX) di 3 ibu kota provinsi (Kominfo, 2016).
Seiring berkembangnya TIK, saat ini telah terbentuk suatu era baru industri yang diberi nama Revolusi Industri 4.0. Revolusi Industri 4.0 merupakan wujud dari kehadiran TIK yang telah memengaruhi perekonomian. TIK dengan revolusi industri 4.0 turut membentuk pola khusus yang menghubungkan kemajuan teknologi, efisiensi, dan efektivitas manusia (Apri, 2015).

Pertumbuhan neo klasik melihat perekonomian dari sisi penawaran. Model pertumbuhan Solow (Solow Growth Model) menghasilkan hubungan ketersediaan modal, angkatan kerja dan kemajuan teknologi dalam suatu perekonomian dan bagaimana pengaruhnya terhadap output total barang dan jasa pada suatu negara (Mankiw, 2007). Dalam teori neoklasik, faktor terpenting untuk mewujudkan pertumbuhan ekonomi bukanlah penambahan modal dan penambahan tenaga kerja, melainkan kemajuan teknologi dan penambahan kemahiran dan kepakaran tenaga kerja (Sukirno, 2011). Dengan teknologi yang mengalami kemajuan, pengetahuan masyarakat tentang metode-metode produksi bertambah dan efisiensi meningkat. Jhingan, (2004) mengatakan bahwa kemajuan teknologi akan merubah hal-hal yang terkait dengan metode produksi yang akan memengaruhi perekonomian.

Dampak perkembangan TIK terhadap perekonomian tidak hanya dirasakan pada tingkat nasional tetapi hingga tingkat daerah, salah satunya di Provinsi Banten. Berdasarkan data Badan Pusat Statistik (BPS), Pertumbuhan Ekonomi Provinsi Banten pada tahun 2019 mencapai 5,29 persen. Angka ini menunjukkan penurunan apabila dibandingkan tahun 2018 yang mencapai 5,77 persen. Kontribusi lapangan usaha informasi 
dan komunikasi terhadap perekonomian Provinsi Banten sebesar 3,52 persen pada tahun 2019. Produk Domestrik Regional Bruto (PDRB) lapangan usaha informasi dan komunikasi Provinsi Banten tumbuh 8,98 persen pada tahun 2019.

Secara bahasa, teknologi informasi merupakan studi atau peralatan elektronika, terutama komputer, untuk menyimpan, menganalisis, dan mendistribusikan informasi apa saja, termasuk kata-kata, bilangan, dan gambar (Kamus Oxford, 1995). Berdasarkan data Badan Pusat Statistik (BPS), sekitar 15,27 persen penduduk Banten yang berumur 5 tahun keatas menggunakan komputer pada tahun 2019. Seperti halnya pertumbuhan ekonomi, persentase pengguna komputer di Provinsi Banten juga mengalami penurunan apabila dibandingkan tahun 2018 dimana pada tahun 2018 mencapai 22,93 persen.

Menurut Martin (1999), teknologi informasi tidak hanya terbatas pada teknologi komputer (perangkat lunak dan perangkat keras) yang digunakan untuk memproses atau menyimpan informasi, melainkan mencakup teknologi komunikasi untuk mengirimkan informasi. Telepon seluler yang biasa disebut sebagai telepon portable atau handphone (HP) merupakan sebuah alat komunikasi praktis yang dapat menghubungkan individu satu dengan individu lainnya. World Bank mendefinisikan telepon seluler sebagai langganan telepon seluler yang memberikan layanan telepon di sektor publik serta menyediakan akses ke PSTN (Public Switched Telephone Network).

Berdasarkan data Badan Pusat Statistik (BPS), sekitar 73,03 persen penduduk Banten yang berumur 5 tahun keatas menggunakan telepon selular (HP) pada tahun 2019. Berbeda halnya dengan penurunan persentase pengguna komputer, persentase pengguna telepon seluler justru menunjukkan kenaikan apabila dibandingkan tahun 2018 dimana pada tahun 2018 mencapai 72,22 persen.

Hasil penelitian yang dilakukan oleh Retiawan \& Saleh (2011), Lum Tracy (2011), Cahyono, (2012), Lee, dkk (2012), Anupam Das, dkk (2015), Adonsou, dkk (2016), Săglam (2016), Qureshi \& Najjar (2017), Ariansyah (2018) menunjukan variabel pengguna telepon seluler secara signifikan berpengaruh positif terhadap pertumbuhan ekonomi. Hal tersebut menunjukkan pengguna telepon seluler berperan penting dalam perekonomian, khususnya ekonomi digital. Keberadaan pengguna telepon seluler akan mendukung produktivitas ekonomi digital yang pada waktunya akan meningkatkan pendapatan per kapita. Semakin banyaknya pengguna seluler, aksesbilitas masyarakat terhadap informasi dan komunikasi semakin terbuka lebar.

Pengguna komputer dan telepon seluler turut mendukung masyarakat dalam mengakses internet. Defleur dan Dennis dalam Zin, Muda \& Nordin (2013) menjelaskan bahwa internet merupakan sistem yang menjadikan sarana umum sebagai penghubung perangkat keras dan transmisi informasi digital, komunitas dengan media sosial dan mendistribusikan sistem informasinya secara global dan telah dikomputerisasi. Keberadaan internet memungkinkan satu individu terhubung dengan satu atau lebih individu lainnya baik untuk berkomunikasi, menerima serta menyebarkan informasi. Internet mendukung efisiensi pasar, menciptakan peluang ekonomi, dan mempromosikan partisipasi politik (UNDP, 2011). Selanjutnya, ini akan meningkatkan perekonomian suatu wilayah.

Berdasarkan data Badan Pusat Statistik (BPS), sekitar 56,25 persen 
penduduk Banten yang berumur 5 tahun keatas mengakses internet pada tahun 2019. Seperti halnya persentase pengguna telepon seluler, persentase pengguna internet di Provinsi Banten meningkat dibandingkan tahun 2018 dimana pada tahun 2018 mencapai 47,90 persen.

Berdasarkan penjabaran diatas, tujuan dari penelitian ini adalah untuk menganalisis pengaruh akses teknologi informasi dan komunikasi terhadap pertumbuhan ekonomi di Provinsi Banten. Adapun hipotesis yang digunakan dalam penelitian ini adalah diduga akses teknologi informasi dan komunikasi yang diukur dengan persentase pengguna komputer, telepon seluler, dan internet berpengaruh terhadap pertumbuhan ekonomi di Provinsi Banten tahun 2015-2019.

\section{METODE PENELITIAN Jenis dan Sumber Data}

Data yang digunakan dalam penelitian ini merupakan data sekunder yang diperoleh dari Badan Pusat Statistik (BPS). Adapun data yang digunakan adalah data tahun 20152019 untuk 8 Kabupaten/ Kota di Provinsi Banten. Penentuan periode waktu penelitian mempertimbangkan ketersediaan data. Wilayah penelitian mencakup seluruh kabupaten/ kota di Provinsi Banten yakni Kabupaten Pandeglang, Kabupaten Lebak, Kabupaten Tangerang, Kabupaten Serang, Kota Tangerang, Kota Cilegon, Kota Serang, dan Kota Serang. Variabel dependen dalam penelitian yaitu pertumbuhan ekonomi sedangkan variabel independen dalam penelitian ini adalah akses teknologi informasi dan komunikasi yang diukur melalui tiga variabel yakni variabel persentase anggota rumah tangga berusia 5 tahun $\mathrm{ke}$ atas yang menggunakan komputer (PC/ desktop, laptop/ notebook, tablet), persentase anggota rumah tangga berusia 5 tahun ke atas yang menggunakan telepon seluler (HP)/ nirkabel, dan persentase anggota rumah tangga berusia 5 tahun ke atas yang mengakses internet (termasuk facebook, twitter, BBM, Whatsapp).

\section{Metode Analisis Data}

Metode analisis yang digunakan dalam penelitian ini adalah analisis deskriptif dan regresi data panel. Regresi data panel merupakan gabungan dari data individu (cross section) dan data deret waktu (time series), hal ini berimplikasi kepada jumlah pengamatan yang menjadi sangat banyak (Gujarati \& Porter, 2004). Jumlah pengamatan yang banyak tersebut dapat memperbesar derajat kebebasan (degree of freedom) dan menurunkan kolinearitas antar variabel (Ekananda, 2018). Ada tiga macam teknik yang dapat digunakan untuk mengestimasi parameter model dalam data panel, yaitu :

\section{1) Common Effect Model}

Common Effect Model merupakan teknik yang paling sederhana untuk mengestimasi data panel, yaitu dengan mengkombinasikan data time series dan cross section dalam bentuk pool dimana teknik estimasinya menggunakan pendekatan kuadrat terkecil/ Ordinary Least Square (OLS). Model ini mengansumsikan slope dan intercept yang konstan antar individu dan waktu. Persamaan regresi common effect model dapat ditulis sebagai berikut:

$$
\begin{aligned}
& y_{i t}=\alpha+\boldsymbol{\beta} \boldsymbol{x}_{i t}+\varepsilon_{i t} \\
& \mathrm{i}=1,2,3, \ldots, \mathrm{N} \text { dan } \\
& \mathrm{t}=1,2,3, \ldots, \mathrm{T}
\end{aligned}
$$

\section{2) Fixed Effect Model}

Fixed Effect Model mengasumsikan perbedaan antar individu dapat ditangkap pada perbedaan intercept nya. Oleh karena itu, setiap $\alpha_{i}$ diperlakukan sebagai parameter yang 
tidak diketahui dan akan diestimasi. Secara umum, persamaan regresi Fixed Effect Model dapat dituliskan sebagai berikut:

$$
y_{i t}=\alpha_{i}+\boldsymbol{\beta} \boldsymbol{x}_{i t}+\varepsilon_{i t}
$$

\section{3) Random Effect Model}

Random Effect Model menggunakan variabel residual untuk mengakomodasi perbedaan karakteristik individu dan waktu. Dengan demikian, dalam Random Effect Model terdapat dua komponen residual, yaitu residual cross section $\varepsilon_{\mathrm{i}}$ dan kombinasi residual cross section dan time series $\mathrm{u}_{\mathrm{it}}$. Persamaan regresi untuk Random Effect Model dapat dituliskan sebagai berikut:

$$
\begin{gathered}
y_{i t}=\alpha_{i}+\boldsymbol{\beta} \boldsymbol{x}_{\boldsymbol{i t}}+\varepsilon_{i}+u_{i t} \\
=\alpha_{i}+\boldsymbol{\beta} \boldsymbol{x}_{\boldsymbol{i t}}+w_{i t} \\
\text { di mana: } \\
w_{i t}=\varepsilon_{i}+u_{i t}
\end{gathered}
$$

Model yang akan digunakan untuk menjelaskan pengaruh akses teknologi informasi dan komunikasi terhadap pertumbuhan ekonomi seluruh kabupaten/ kota di Provinsi Banten tahun 2016-2019 dalam penelitian ini adalah random effect model dengan persamaan sebagai berikut:

$$
\begin{aligned}
\mathrm{PE}_{\mathrm{it}}= & \left(\alpha+\varepsilon_{\mathrm{i}}\right)+\beta_{1} \text { Komputer }_{i t}+\beta_{2} \text { Seluler }_{\mathrm{it}}+ \\
& \beta_{3} \text { Internet }_{\mathrm{it}}+\mathrm{u}_{\mathrm{it}}
\end{aligned}
$$

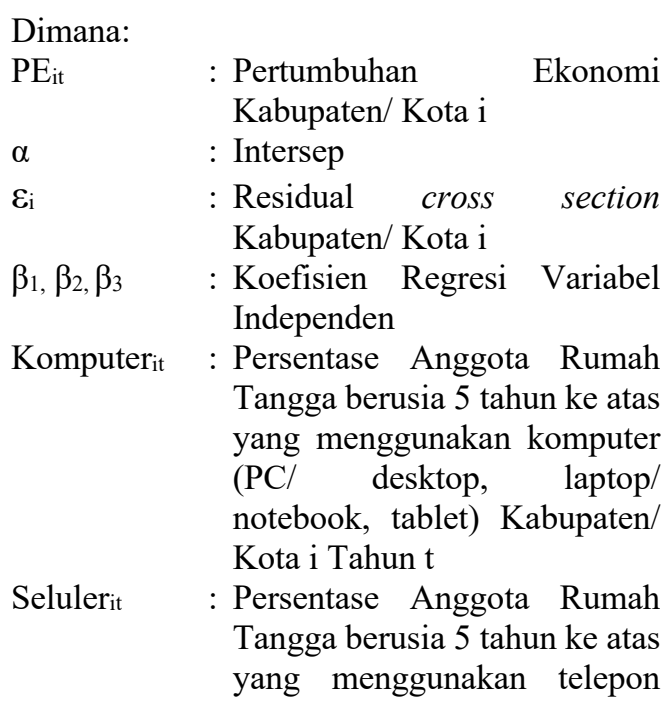

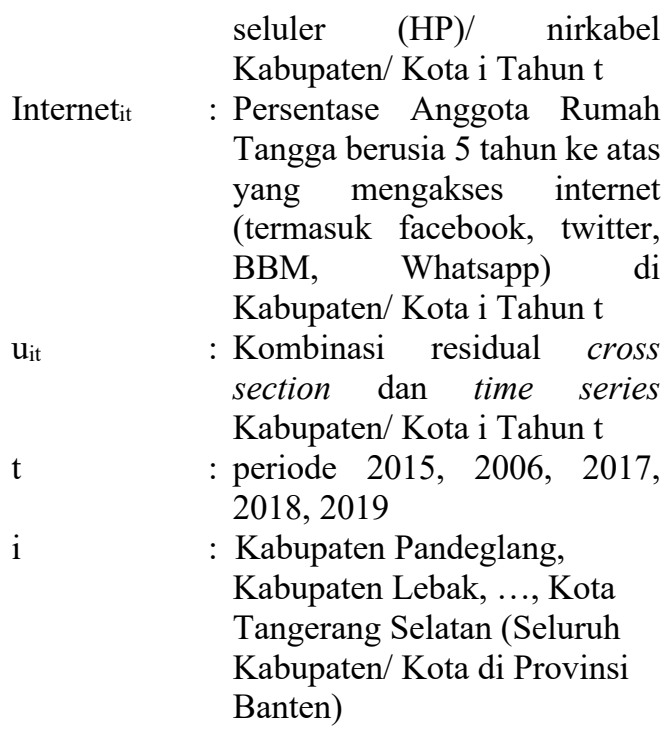

Agar memperoleh penduga yang bersifat BLUE (Best Linier Unbiased Estimator), pada penelitian ini dilakukan berbagai pengujian terhadap data dan model yang terbentuk, seperti uji asumsi dasar (uji Normalitas, Homoskedastisitas, NonAutokorelasi, dan Non Multikolinearitas) serta Uji Keberartian Model (Uji F dan Uji t).

\section{ANALISIS DATA DAN PEMBAHASAN \\ Laju Pertumbuhan Ekonomi, Persentase Pengguna Komputer, Persentase Pengguna Telepon Seluler, dan Persentase Pengguna Internet di Provinsi Banten Tahun 2015-2019}

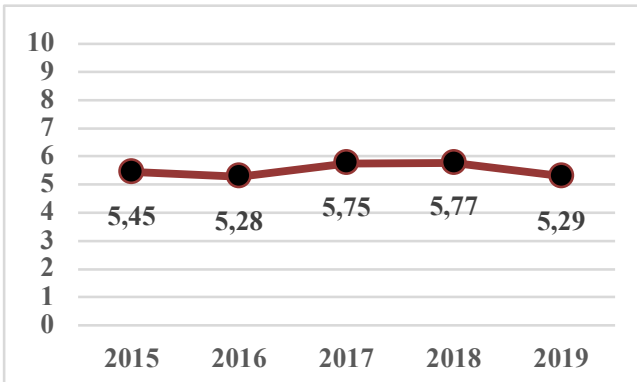

Gambar 1. Laju Pertumbuhan Ekonomi Provinsi Banten Tahun 2015-2019 (persen)

Secara umum, pertumbuhan ekonomi Provinsi Banten selama kurun waktu tahun 2015-2019 menunjukkan fluktuasi namun tidak begitu besar. Laju pertumbuhan ekonomi Provinsi 
Banten sempat melambat pada tahun 2016. Namun, tumbuh kembali pada tahun 2017 hingga 2018. Pada tahun 2019, Pertumbuhan ekonomi Provinsi Banten kembali melambat.

Basuki dan Gayatri (2009) mengatakan bahwa Otonomi Daerah turut serta dalam memengaruhi pertumbuhan ekonomi suatu daerah. Otonomi daerah menuntut suatu daerah bertanggung jawab dalam mengatur pembangunan daerahnya sendiri.

Berdasarkan Gambar 2, diperoleh informasi bahwa Kota Tangerang
Selatan memiliki pertumbuhan ekonomi tertinggi dibandingkan seluruh kabupaten/ kota di Provinsi Banten pada tahun 2019, yakni mencapai 7,35 persen. Kemudian, disusul oleh Kota Serang yang mencapai 6,44 persen. Sebaliknya, Kota Tangerang memiliki pertumbuhan ekonomi terendah dibandingkan seluruh kabupaten/ kota di Provinsi Banten pada tahun 2019, yakni mencapai 4,30 persen.

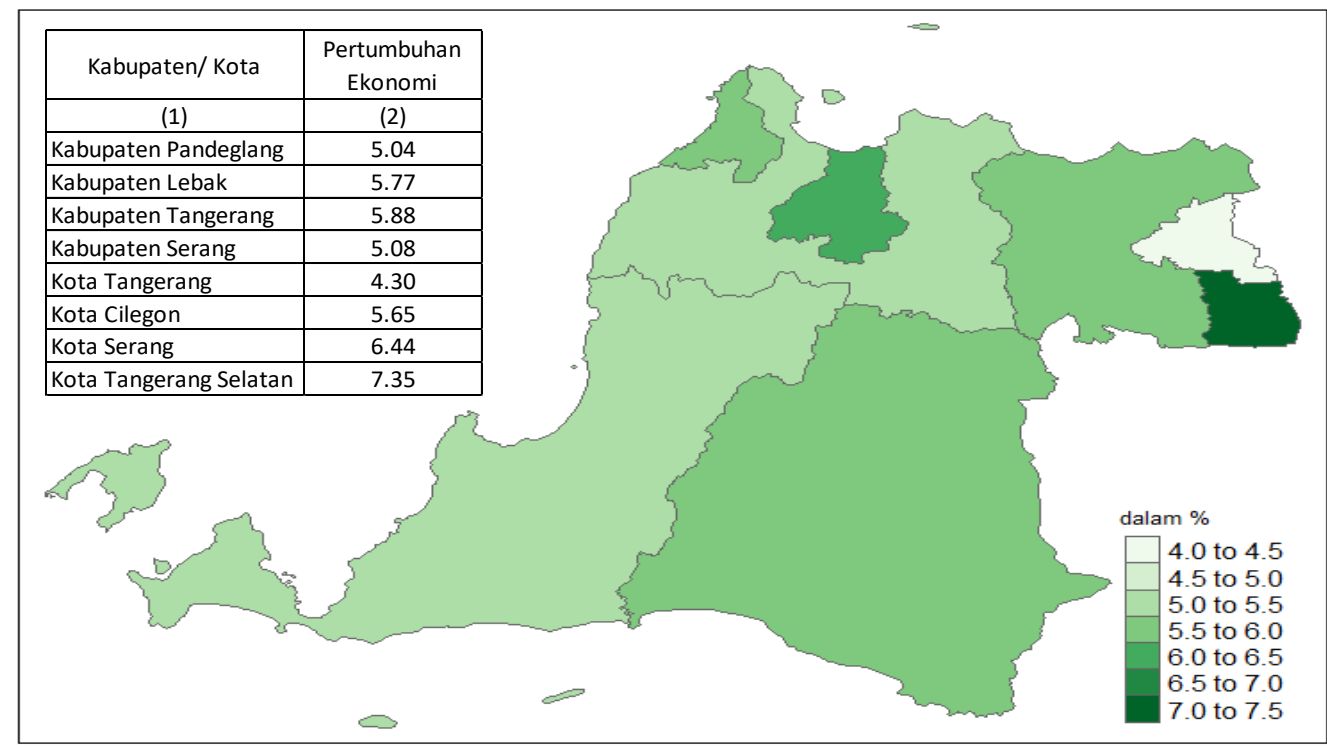

Gambar 2. Pertumbuhan Ekonomi Kabupaten/ Kota di Provinsi Banten Tahun 2019 (persen)

Jhingan, (2004) mengatakan bahwa kemajuan teknologi akan merubah hal-hal yang terkait dengan metode produksi yang akan mempengaruhi perekonomian. Persentase pengguna komputer merupakan salah satu indikator kemajuan teknologi suatu wilayah. Dalam penelitian ini, komputer mengacu pada komputer desktop, laptop (portable) atau tablet (atau komputer genggam yang serupa).

Persentase pengguna komputer di Provinsi Banten terus menunjukkan peningkatan selama tahun 2015 hingga 2018. Namun, pada tahun 2019 persentase pengguna komputer menunjukkan penurunan yakni mencapai 15,27 persen.

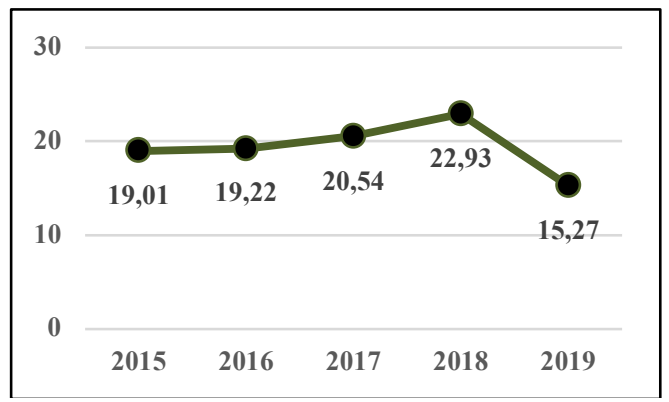

Gambar 3. Perkembangan Persentase Pengguna Komputer di Provinsi Banten Tahun 2015-2019 (persen)

Sama halnya dengan pencapaian pertumbuhan ekonomi, persentase pengguna komputer di Kota Tangerang 
Selatan tertinggi dibandingkan seluruh kabupaten/ kota di Provinsi Banten pada tahun 2019, yakni mencapai 31,12 persen. Sebaliknya, persentase pengguna komputer di Kabupaten
Lebak terendah dibandingkan seluruh kabupaten/ kota di Provinsi Banten pada tahun 2019, yakni mencapai 5,27 persen.

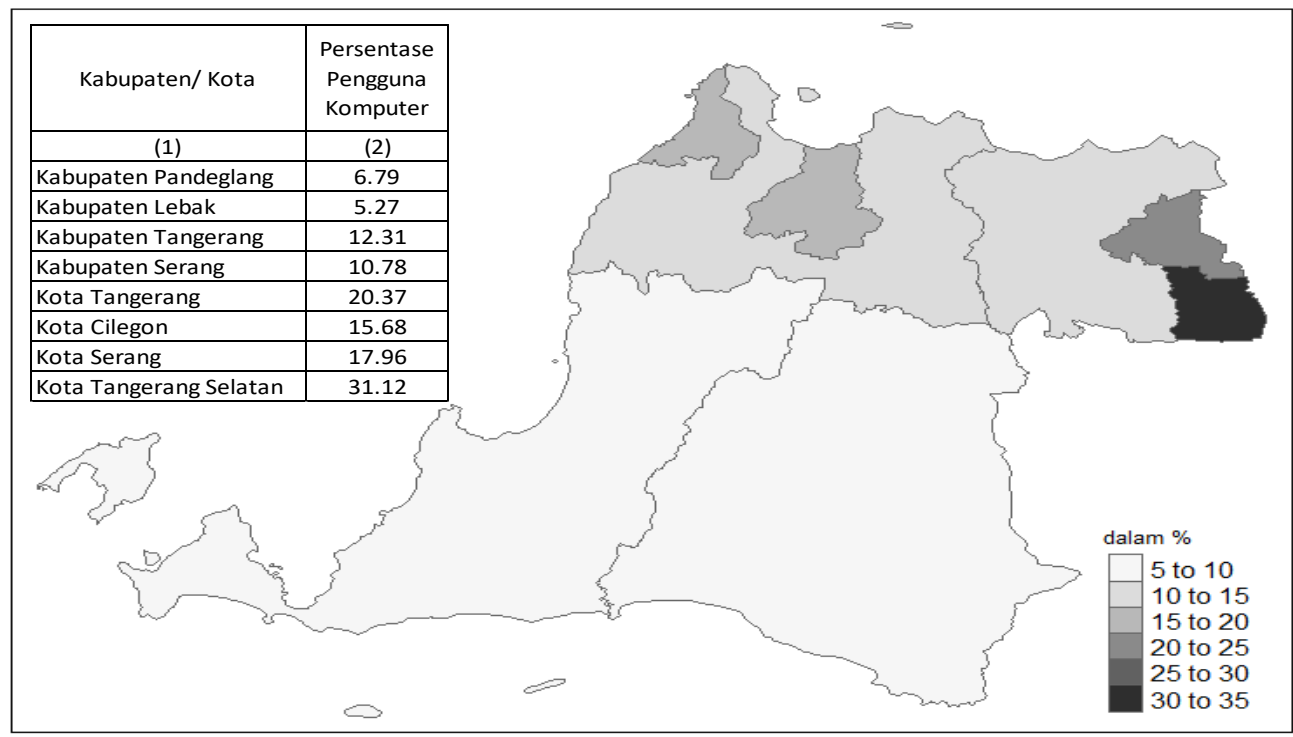

Gambar 4. Persentase Anggota Rumah Tangga 5 Tahun Keatas yang Menggunakan Komputer pada Kabupaten/ Kota di Provinsi Banten Tahun 2019 (persen)

Selain persentase pengguna komputer, persentase pengguna telepon seluler juga dapat menjadi indikator kemajuan teknologi informasi dan komunikasi suatu daerah. Dalam penelitian ini, telepon seluler (HP) mengacu pada perangkat telekomunikasi elektronik yang mempunyai kemampuan dasar yang sama dengan telepon tetap kabel, namun dapat dibawa ke mana-mana (portable mobile) dan tidak perlu disambungkan dengan jaringan telekomunikasi kabel. Termasuk telepon seluler adalah handphone dan smartphone, tetapi tidak termasuk tablet meskipun bisa digunakan untuk menelepon.

Persentase pengguna telepon seluler, dalam hal ini anggota rumah tangga 5 tahun keatas yang menggunakan telepon seluler di Provinsi Banten cenderung menunjukkan kenaikan selama tahun 2015 hingga 2019. Pada tahun 2015, persentase pengguna telepon seluer di Provinsi Banten mencapai 60,49 persen dan terus meningkat hingga tahun 2019 hingga mencapai 73,03 persen.

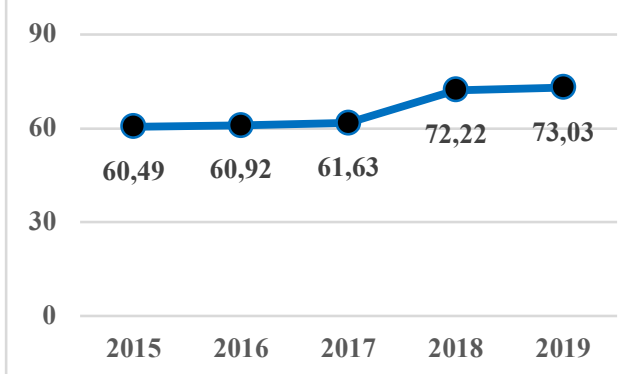

Gambar 5. Perkembangan Persentase Pengguna Telepon Seluler di Provinsi Banten Tahun 2015-2019 (persen)

Berdasarkan gambar 6, terlihat bahwa persentase pengguna telepon seluler tertinggi terdapat di Kota Tangerang Selatan pada tahun 2019 yakni mencapai 84,70 persen. Selanjutnya, disusul oleh KotaTangerang yang mencapai 80,68 
persen. Sebaliknya, persentase pengguna telepon seluler terendah terdapat di Kabupaten Lebak apabila dibandingkan kabupaten/ kota di Provinsi Banten, yakni mencapai 60,60 persen pada tahun 2019.

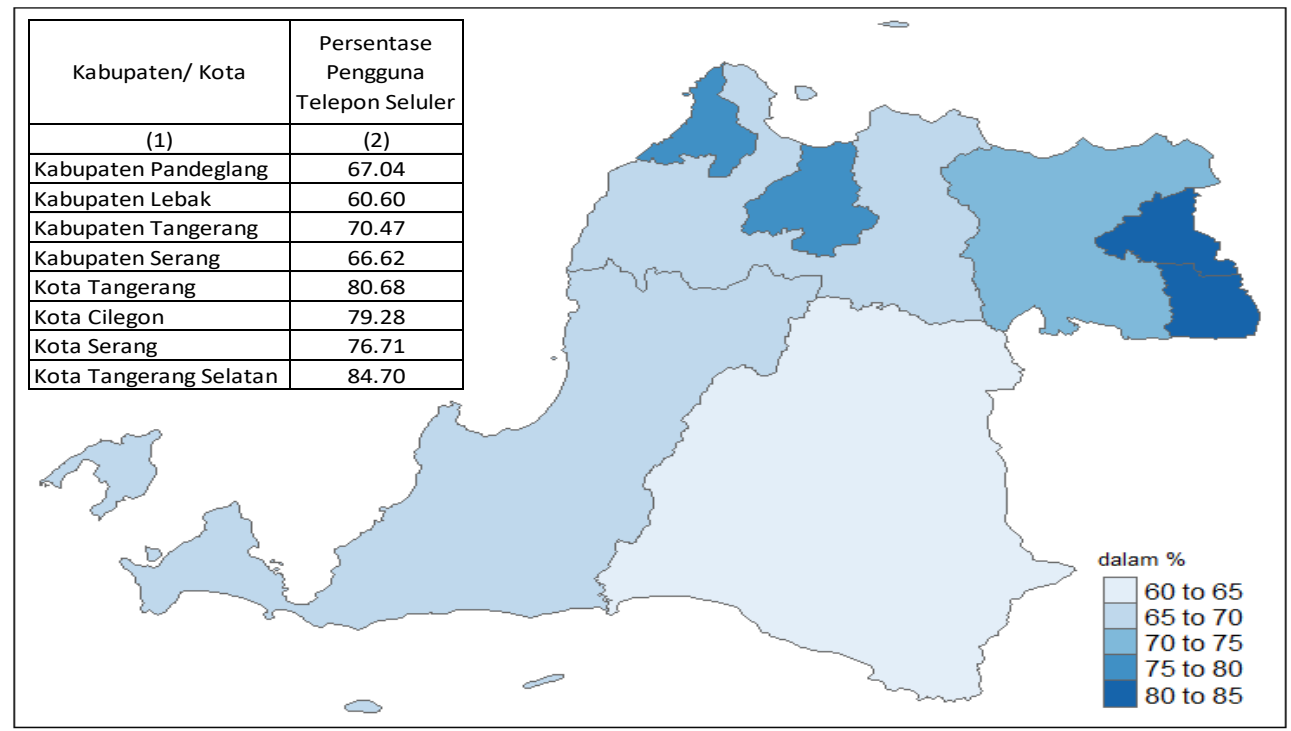

Gambar 6. Persentase Anggota Rumah Tangga 5 Tahun Keatas yang Menggunakan Telepon Seluler pada Kabupaten/ Kota di Provinsi Banten Tahun 2019 (persen)

Pengguna telepon seluler turut mendukung masyarakat dalam mengakses internet. Semakin banyaknya pengguna seluler, aksesbilitas masyarakat terhadap informasi dan komunikasi semakin terbuka lebar. Dengan demikian, persentase pengguna internet dapat menjadi Indikator kemajuan teknologi informasi dan komunikasi.

Persentase anggota rumah tangga berumur 5 tahun keatas yang menggunakan internet di Provinsi Banten terus menunjukkan kenaikan yang signifikan. Pada tahun 2015, sekitar 26,22 persen anggota rumah tangga berumur 5 tahun keatas di Provinsi Banten menggunakan internet. Angka ini terus meningkat hingga tahun 2019 sekitar 56,25 persen anggota anggota rumah tangga berumur 5 tahun keatas di Provinsi Banten menggunakan internet.

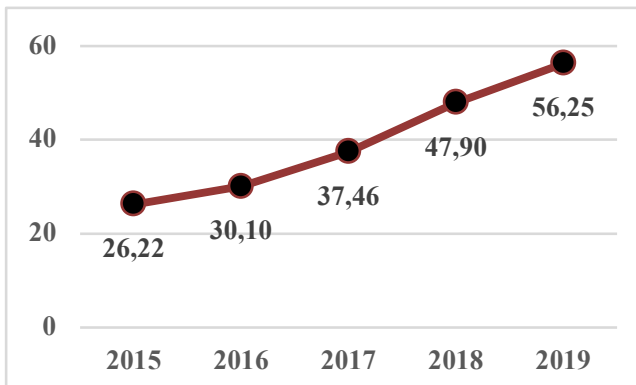

Gambar 7. Perkembangan Persentase

Pengguna Internet di Provinsi Banten Tahun 2015-2019 (persen)

Peningkatan kemudahan akses internet perlu diperhatikan lebih lanjut untuk memudahkan manusia dalam melakukan transaksi bisnis atau kegiatan produksi. Berdasarkan Gambar 8, terlihat bahwa persentase pengguna internet tertinggi terdapat di Kota Tangerang Selatan pada tahun 2019 yakni mencapai 78,35 persen. Selanjutnya, disusul oleh Kota Tangerang yang mencapai 71,49 persen. Sebaliknya, persentase pengguna internet terendah terdapat di Kabupaten Lebak apabila dibandingkan kabupaten/ kota di 
Provinsi Banten, yakni mencapai 28,72

persen pada tahun 2019.

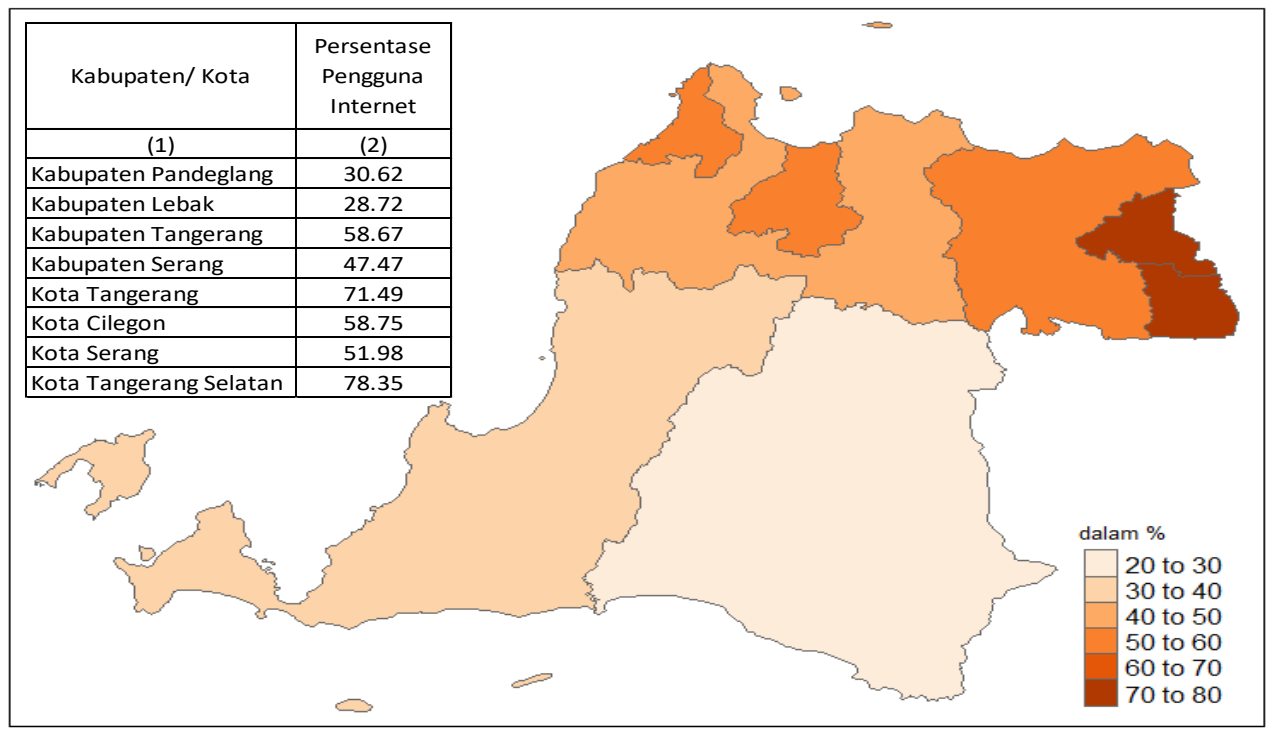

Gambar 8. Persentase Anggota Rumah Tangga 5 Tahun Keatas yang Menggunakan Internet pada Kabupaten/ Kota di Provinsi Banten Tahun 2019 (persen)

\section{Pengujian Asumsi Model Regresi Linier Klasik}

Untuk mengetahui seberapa besar pengaruh variabel independen terhadap variabel dependen, dilakukan pembentukkan model dengan analisis regresi data panel. Uji Hausman dilakukan untuk mengetahui model regresi data panel yang lebih baik antara Fixed Effects Model (FEM) atau Random Effects Model (REM). Dalam pengujian ini, hipotesis nolnya adalah model random effects yang terpilih dan hipotesis alternatifnya adalah model fixed effects yang terpilih.

Melalui program $R$ Studio, diperoleh nilai probabilitas dari statistik Chi-Square dari Hausman Test sebesar 0,752 dan nilai probabilitas ini lebih besar dari alpha 0,05 sehingga hipotesis nol diterima. Dengan demikian, dapat disimpulkan bahwa dengan tingkat kepercayaan 95 persen, minimal ada satu intercept kabupaten/ kota yang berbeda dan intercept bersifat stokastik/ acak. Hal ini mengindikasikan bahwa random effects model lebih baik daripada fixed effects model sehingga model terbaik yang terpilih dalam penelitian ini adalah Random Effects Model (REM).

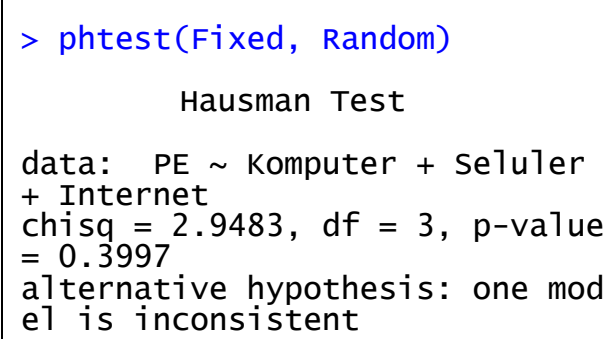

Gambar 9. Hasil Uji Hausman dengan Software R Studio

Adapun output $R$ Studio dari Random Effect Model (REM) yang digunakan dalam penelitian ini adalah sebagai berikut: 


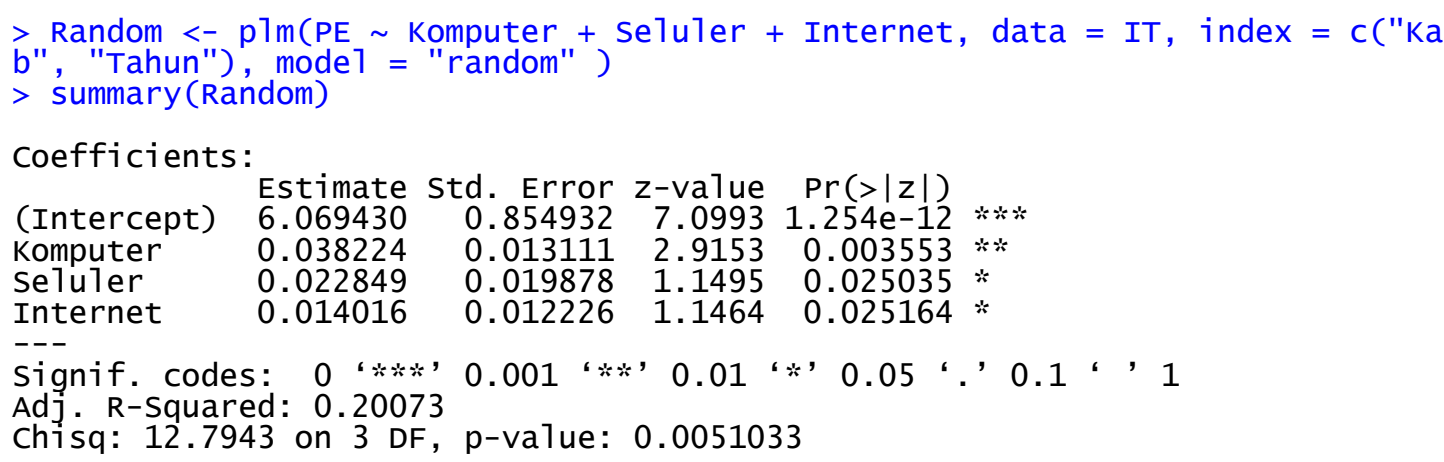

Gambar 10. Estimasi Random Effect Model (REM) dengan Software R Studio

Varians residual dari model yang terbentuk bersifat homoskedastis. Hal ini dibuktikan dengan seluruh variabel independen tidak secara signifikan berpengaruh terhadap nilai absolut residual dari model yang terbentuk (nilai probabilitas (P-value) dari Breusch-Pagan test $(0,1806)$ lebih besar dari alpha 0,05 (terima $\mathrm{H}_{0}$ ).

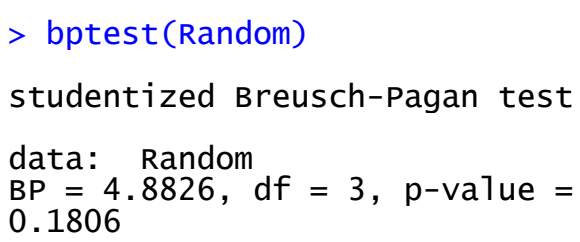

Gambar 11. Hasil Pengujian Asumsi Homoskedastiditas dengan Uji Breusch Pagan Melalui Software R Studio

Asumsi non-autokorelasi pada model yang terbentuk juga telah terpenuhi. Hal ini dibuktikan dengan nilai $P$-Value dari Durbin-Watson test $(0,0864)$ lebih besar dari alpha 0,05 (terima $\mathrm{H}_{0}$ ).

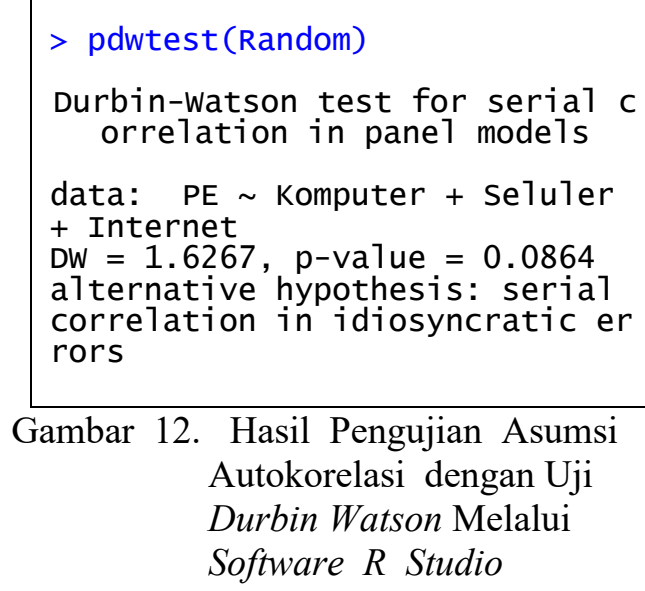

Gambar 12. Hasil Pengujian Asumsi Autokorelasi dengan Uji Durbin Watson Melalui Software $R$ Studio

Pengujian asumsi nonmultikolinieritas pada penelitian ini menggunakan uji formal yakni berdasarkan nilai Variance Inflation Factor (VIF). Dengan menggunakan software $R$ Studio, diperoleh hasil pengujian asumsi nonmultikolinearitas sebagai berikut:

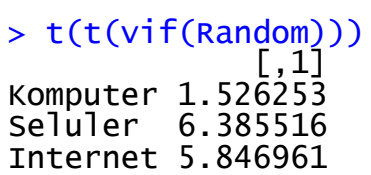

Gambar 13. Hasil Pengujian Asumsi Non- Multikolinearitas dengan VIF Melalui Software $R$ Studio 
Asumsi Non-Multikolinearitas atas seluruh variabel bebas yang digunakan dalam model sudah terpenuhi. Hal ini dibuktikan dengan nilai Variance Inflation Factor (VIF) untuk seluruh variabel jauh lebih kecil dari 10 sehingga dapat disimpulkan tidak terjadi hubungan antara variabel bebas yang masuk ke dalam model.

Berdasarkan uji asumsi dasar di atas, dapat disimpulkan bahwa model yang terbentuk merupakan model terbaik. Model ini dapat digunakan untuk menganalisis pengaruh akses teknologi informasi dan komunikasi terhadap pertumbuhan ekonomi Provinsi Banten tahun 2015-2019.

\section{Pengaruh Akses Teknologi Informasi dan Komunikasi Terhadap Pertumbuhan Ekonomi Provinsi Banten Tahun 2015-2019}

Nilai Adjusted $R$-Square yang diperoleh sebesar 0,2007 yang berarti bahwa keragaman (variasi) data pertumbuhan ekonomi di Provinsi Banten dapat dijelaskan oleh keragaman (variasi) data persentase pengguna komputer, telepon seluler, dan internet sebesar 20,07 persen sedangkan sisanya sebesar 79,93 persen dijelaskan oleh variabel lain yang tidak masuk di dalam model.

Model yang terbentuk fit terhadap data. Hal ini ditunjukkan dengan nilai probabilitas uji ChiSquare sebesar 0,0051 yang lebih kecil dari alpha 0,05 . Ini berarti model yang terbentuk dapat digunakan untuk menjelaskan pengaruh akses teknologi informasi dan komunikasi yang diukur dengan variabel persentase pengguna komputer, telepon seluler, dan internet terhadap pertumbuhan ekonomi kabupaten/ kota di Provinsi Banten tahun 2015-2019.

Secara parsial, persentase pengguna komputer secara signifikan berpengaruh positif terhadap pertumbuhan ekonomi kabupaten/ kota di Provinsi Banten tahun 2015-2019. Hal ini ditunjukkan dengan nilai $p$ value uji $t$-statistic $(0,0035)$ lebih kecil dari alpha 0,05 dan nilai koefisien regresi bernilai positif. Nilai koefisien regresi dari variabel persentase pengguna komputer sebesar 0,0382 menunjukkan bahwa dengan tingkat kepercayaan 95 persen jika persentase pengguna komputer meningkat 1 persen maka pertumbuhan ekonomi kabupaten/ kota di Provinsi Banten meningkat sebesar 0,0382 persen. Peningkatan persentase pengguna komputer dapat mengindikasikan permintaan terhadap komputer semakin meningkat. Peningkatan permintaan komputer dapat meningkatkan nilai tambah indutri komputer dan/ atau perakitan komputer di Provinsi Banten. Selain itu, hal ini pun dapat meningkatkan nilai tambah usaha perdagangan serta reparasi komputer dan perlengkapannya. Selanjutnya, ini akan meningkatkan pertumbuhan ekonomi Provinsi Banten. Dalam pemanfaatannya, penggunaan komputer dapat meningkatkan produktivitas tenaga kerja karena mempercepat penyelesaian suatu kegiatan. Ini akan mendorong efisiensi pengeluaran biaya untuk penambahan tenaga kerja sehingga biaya input dari suatu usaha berkurang. Kemudian, dapat meningkatkan surplus atau nilai tambah suatu usaha. Berdasarkan data Badan Pusat Statistik (BPS), sekitar 15,27 persen penduduk Provinsi Banten menggunakan komputer pada tahun 2019. Angka ini menunjukan penurunan apabila dibandingkatan tahun 2018 yang mencapai 22,93 persen. Penurunan ini diiringi dengan penurunan pertumbuhan ekonomi Provinsi Banten yang mencapai 5,29 persen pada tahun 2019 sedangkan pada tahun 2018 mencapai 5,77 persen.

Persentase pengguna telepon seluler secara signifikan berpengaruh 
positif terhadap pertumbuhan ekonomi kabupaten/ kota di Provinsi Banten tahun 2015-2019. Hal ini ditunjukkan dengan nilai $p$-value uji t-statistic $(0,0250)$ lebih kecil dari alpha 0,05 dan nilai koefisien regresi bernilai positif. Nilai koefisien regresi dari variabel persentase pengguna telepon seluler sebesar 0,0228 menunjukkan bahwa dengan tingkat kepercayaan 95 persen jika persentase pengguna telepon seluler meningkat 1 persen maka pertumbuhan ekonomi kabupaten/ kota di Provinsi Banten meningkat sebesar 0,0228 persen. Pengaruh positif persentase pengguna telepon seluer terhadap pertumbuhan ekonomi serupa dengan penelitian yang dilakukan Retiawan \& Saleh (2011), Lum Tracy (2011), Cahyono, (2012), Lee, dkk (2012), Anupam Das, dkk (2015), Adonsou, dkk (2016), Săglam (2016), Qureshi \& Najjar (2017), Ariansyah (2018).

Semakin banyaknya pengguna seluler, aksesbilitas masyarakat terhadap informasi dan komunikasi semakin terbuka lebar. Ini akan mempercepat aktivitas ekonomi suatu wilayah. Peningkatan permintaan telepon seluler dapat meningkatkan nilai tambah industri peralatan komunikasi di Provinsi Banten. Peningkatan permintaan telepon seluler dapat meningkatkan nilai tambah indutri industri peralatan komunikasi di Provinsi Banten. Selain itu, hal ini pun dapat meningkatkan nilai tambah usaha perdagangan serta reparasi telepon seluler dan perlengkapannya. Selanjutnya, ini akan mengakibatkan laju pertumbuhan Produk Domestik Regional Bruto (PDRB) Provinsi Banten naik. Berdasarkan data Badan Pusat Statistik (BPS), sekitar 73,03 persen penduduk Provinsi Banten menggunakan telepon seluler pada tahun 2019. Angka ini menunjukan peningkatan apabila dibandingkatan tahun 2018 yang mencapai 72,22 persen. Peningkatan ini diiringi dengan pertumbuhan PDRB subkategori perdagangan besar dan eceran bukan mobil dan sepeda motor yang mencapai 6,44 persen. Kontribusi subkategori perdagangan besar dan eceran bukan mobil dan sepeda motor terhadap perekonomian Provinsi Banten sebesar 11,06 persen. Dengan demikian, pertumbuhan PDRB subkategori ini juga mengakibatkan PDRB Provinsi Banten tumbuh sebesar 5,29 persen pada tahun 2019 .

Peningkatan pengguna telepon seluler turut mendukung peningkatan pengguna internet. Persentase pengguna internet secara signifikan berpengaruh positif terhadap pertumbuhan ekonomi kabupaten/ kota di Provinsi Banten tahun 2015-2019. Hal ini ditunjukkan dengan nilai $p$ value uji $t$-statistic $(0,0252)$ lebih kecil dari alpha 0,05 dan nilai koefisien regresi bernilai positif. Nilai koefisien regresi dari variabel persentase pengguna internet sebesar 0,0140 menunjukkan bahwa dengan tingkat kepercayaan 95 persen jika persentase pengguna internet meningkat 1 persen maka pertumbuhan ekonomi kabupaten/ kota di Provinsi Banten meningkat sebesar 0,0140 persen. Menurut UNDP (2011), internet mendukung efisiensi pasar serta menciptakan peluang ekonomi. Dengan demikian, akan tercipta iklim perekonomian yang efektif dan efisien serta terbentuknya pasar yang baru. Kemudian, ini akan mendorong peningkatan pendapatan per kapita masyarakat.

Peningkatan permintaan akses terhadap internet di Provinsi Banten akan mengakibatkan aktivitas usaha jasa telekomunikasi meningkat. Secara makro, ini akan meningkatkan PDRB Subkategori Telekomunikasi di Provinsi Banten. Pada akhirnya, ini akan mengakibatkan laju pertumbuhan Produk Domestik Regional Bruto 
(PDRB) Provinsi Banten naik. Berdasarkan data Badan Pusat Statistik (BPS), sekitar 56,25 persen penduduk Provinsi Banten menggunakan internet pada tahun 2019. Angka ini menunjukan peningkatan apabila dibandingkatan tahun 2018 yang mencapai 47,90 persen. Peningkatan ini diiringi dengan pertumbuhan PDRB subkategori informasi dan komuniksi yang mencapai 8,98 persen. Kontribusi subkategori informasi dan komunikasi terhadap perekonomian Provinsi Banten sebesar 3,52 persen. Dengan demikian, pertumbuhan PDRB subkategori ini juga mengakibatkan PDRB Provinsi Banten tumbuh sebesar 5,29 persen pada tahun 2019 .

Selain itu, keberadaan internet berperan dalam peningkatan surplus usaha perdagangan barang dan jasa secara online. Berdasarkan data Badan Pusat Statistik (BPS), sekitar 13,96 persen penduduk Banten berumur 5 tahun ke atas mengakses internet untuk keperluan pembelian barang/ jasa pada tahun 2019. Kemudian, sekitar 12,66 persen penduduk Banten berumur 5 tahun ke atas mengakses internet untuk mendapat informasi barang barang/ jasa pada tahun 2019. Namun demikian, hanya sekitar 3,47 persen penduduk Banten berumur 5 tahun ke atas mengakses internet untuk keperluan penjualan barang/ jasa pada tahun 2019.

Dengan adanya internet, pengetahuan masyarakat tentang metode-metode produksi akan bertambah karena internet memberikan kemudahan masyarakat untuk mengakses informasi. Berdasarkan data Badan Pusat Statistik (BPS), sekitar 71,21 persen penduduk Banten berumur 5 tahun ke atas mengakses internet untuk menacri informasi/ berita pada tahun 2019. Kemudian, sekitar 19,58 persen penduduk Banten berumur 5 tahun ke atas mengakses internet untuk menacri informasi pembelajaran pada tahun 2019

\section{KESIMPULAN}

Masih terdapat disparitas akses teknologi informasi dan komunikasi pada seluruh kabupaten/ kota di Provinsi Banten tahun 2015-2019. Akses Teknologi Informasi dan Komunikasi secara signifikan berpengaruh positif terhadap pertumbuhan ekonomi kabupaten/ kota di Provinsi Banten Tahun 2015-2019. Dengan demikian, pemerintah daerah perlu meningkatkan infrastruktur teknologi informasi dan komunikasi pada seluruh kabupaten/ kota di Provinsi Banten, khususnya pada daerah-daerah yang memiliki tingkat kesulitan dalam hal akses teknologi informasi dan komunikasi. Selain itu, diperlukan upaya peningkatan kualitas penduduk dan tenaga kerja dalam pemanfaatan teknologi informasi dan komunikasi pada seluruh kabupaten/ kota di Provinsi Banten.

Selain pertumbuhan ekonomi, akses teknologi informasi dan komunikasi juga diduga dapat memengaruhi beberapa variabel ekonomi lainnya, misalnya kondisi ketenagakerjaan/ pengangguran. Dengan demikian, diharapkan adanya penelitian lanjutan untuk menganalisis pengaruh akses teknologi informasi dan komunikasi terhadap pengagguran di Provinsi Banten.

\section{DAFTAR PUSTAKA}

Adonsou, Ficawoyi Donou, Sokchea Lim, \& Samuel A Mathey. (2016). Technological Progress and Economic Growth in SubSaharan Africa: Evidence from Telecommunications 
Apri, Junaidi. (2015). Internet of Things, Sejarah, Teknologi, dan Penerapannya: Review. Jurnal Ilmiah Teknologi Informasi Terapan, 1(3).

Ariansyah, Kasmad. (2018). The Importance of The Internet on Improving Economic Welfare: An Empirical Evidence from Indonesian Rural Household. International Conference on ICT for Rural Development (ICICTRuDev)

Cahyono. (2012). Analisis Pengaruh Infrastruktur Ekonomi Terhadap Produk Domestik Bruto di Indonesia. Jurnal Ekonomi Pembangunan, 10(2).

Das, Anupam, Murshed Chowdhury, \& Sariah Seaborn. (2015). ICT Diffusion, Financial Development and Economic Growth: New Evidence from Low and Lower Middle-Income Countries. New York: Springer Science Business Media

Ekananda, M. (2018). Analisis Ekonometrika Data Panel Edisi 2: Teori Lengkap dan Pembahasan Menyeluruh Bagi Peneliti Ekonomi, Bisnis, dan Sosial. Mitra Wacana Media.

Infrastructure. International Atlantic Economic Society.

Gujarati, D. N., \& Porter, D. C. (2004). Basic Econometrics. The McGraw-Hill Series.

Jhingan, M. (2003). Ekonomi Pembangunan dan Perekonomian. Jakarta: PT Raya Grafindo Persada.

Kagermann, H., Lukas, W.D., \& Wahlster, W. (2013). Indusrie 4.0: Mit dem Internet der Dinge auf dem Weg zur 4 industriellen
Revolution.

Kominfo. (2016). Laporan Tahunan Kominfo 2016. Jakarta: Kominfo.

Lee, Sang H., John Levendis, \& Luis Gutierrez.

(2012).

Telecommunications and Economic Growth: An Empirical Analysis of Subsaharan Africa. Applied Economics, 44:46, 461469.

Lum, Tracy. (2011). Mobile Goes Global: The Effect of Cell Phone on Economic Growth and Development.

Mankiw, N. Gregory. (2007). Principle of Macroeconomics. Jakarta: Erlangga.

Martin, E. (1999). Managing Information Technology What Managers Need to Know, 3rd ed. New Jersey: Pearson Education International.

Qureshi, Sajda \& Najjar, Lotfollah. (2017). Information and Communications Technology Use and Income Growth: Evidence of The Multiplier Effect in Very Small Island States. Information Technology for Development, 23:2, 212-234.

Retiawan, Widias \& Saleh, Samsubar. (2017). Pengaruh Teknoligi Informasi dan Komunikasi Terhadap Produk Domestik Bruto Indonesia. Yogyakarta: Universitas Gajah Mada.

Săglam, Bahar Bayraktar. (2016). ICT Diffusion, $R \& D$ Intensity, and Economic Growth: A Dynamic Panel Data Approach. New York: Springer Science Business Media.

Sukirno, Sadono. (2011). Makroekonomi Teori Pengantar Edisi 1 Cetakan 20. Jakarta: Rajawali Pers. 
Jurnal Kebijakan Pembangunan Daerah, Vol.5, No.1, Juni 2021, Hal. 9 - 23

p-ISSN: 2597-4971, e-ISSN: 2685-0079

UNDP. (2001). Human Development

ICT. Report. New York: Oxford University.

UNIDO. (2018). Information and Communications-Technology 